\title{
An emission inventory of sulfur from anthropogenic sources in Antarctica
}

\author{
S. V. Shirsat and H. F. Graf \\ Department of Geography, University of Cambridge, Cambridge, UK
}

Received: 8 October 2008 - Published in Atmos. Chem. Phys. Discuss.: 21 January 2009

Revised: 14 April 2009 - Accepted: 5 May 2009 - Published: 26 May 2009

\begin{abstract}
This paper presents first results of a comprehensive emission inventory of chemical species from anthropogenic activities (power generation, vehicles, ships and aircraft) in Antarctica, covering the 2004-2005 period.

The inventory is based on estimated emission rates of fuel consumption provided by some of the Antarctic research stations. Since the emission sources have different modes of operation and use a variety of fuel, the emission flux rate of chemical species is calculated by multiplying the fuel consumption value with the density of fuel and appropriate emission factors. A separate inventory is prepared for each anthropogenic emission source in Antarctica.

Depending on the type of operation, emission rates of $\mathrm{SO}_{2}$, and BC (Black Carbon, from shipping only) have been calculated using the above technique. However, only results of $\mathrm{SO}_{2}$ emissions from each source are presented here. Emission inventory maps of $\mathrm{SO}_{2}$ depicting the track/path taken by each mobile source are shown. The total annual $\mathrm{SO}_{2}$ is $158 \mathrm{Mg}$ from power generation and vehicle operations, $3873 \mathrm{Mg}$ from ships and $56 \mathrm{Mg}$ from aircraft for 2004-2005 and these values undergo strong seasonality following the human activity in Antarctica. Though these figures are small when compared to the emissions at most other regions of the world, they are an indication that human presence in Antarctica leads to at least local pollution. The sources are mainly line and point sources and thus the local pollution potentially is relatively strong.
\end{abstract}

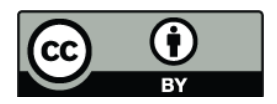

Correspondence to: S. V. Shirsat (ss612@cam.ac.uk)

\section{Introduction}

The climate system of Antarctica is very unique and extreme compared to any other region, making it one of the most pristine (Wall, 2005) places on Earth. Chemical species play an important role in the atmosphere, by affecting air-quality, climate, radiative forcing etc. These effects depend on the type and chemical concentration of the species, place of emission in the atmosphere, climatic conditions of a particular region and emission source. Globally, emissions due to anthropogenic activities account for approximately $70 \mathrm{Tg}(\mathrm{S})$ of the total (natural + anthropogenic) $107 \mathrm{Tg}(\mathrm{S})$ emissions of sulphur each year, although a greater uncertainty exists for natural sources (Smith et al., 2000). In the Arctic, critical concentrations of $\mathrm{SO}_{2}\left(5 \mu \mathrm{g} / \mathrm{m}^{3}\right)$ have been exceeded over a large area and pose damage to ecosystems due to anthropogenic activities (nickel smelters) occurring in the nearby Norilsk region and Kola Peninsula (Kashulina et al., 2003; AMAP report, 1998). In Antarctica, due to growth in tourist and scientist visits to various continental and/or peninsular sites, the impact has started to be recognised and is a cause of concern.

Tourism in Antarctica started during 1950's (Roper-Gee, 2003) with the first flight and ship visits to the Peninsular region. However, in recent years the number of tourists visiting Antarctica has increased from approximately 6000 in 19921993 to 26000 in 2005-2006 (as available from IAATO, International Association of Antarctic Tour Operators), with more than $98 \%$ of them being ship-borne (United States Environment Protection Agency, 2001). In recent years, due to the growth of human activity and visits to Antarctica (IAATO, Overview of Antarctic Tourism, 2003-2004), it is necessary to elucidate the contribution of different emission sources towards concentration levels of chemical species. Earlier local investigations by Lugar (1993) revealed that during the 1992-1993 austral summer PM$_{10}$ levels measured

Published by Copernicus Publications on behalf of the European Geosciences Union. 
at Central McMurdo were comparable to concentrations found in Santa Fe, New Mexico during 1991. A study conducted during $1992-1995$ by Wolff and Cachier (1998) shows that aetholometer readings increased dramatically due to black particle emissions from generators present at Halley research base. Also, Mazzera et al. (2001) in their 19951996, 1996-1997 austral summer study indicate that McMurdo base (located at the Hut Point peninsula on Ross Island) was highly impacted by emissions due to human activities at the base. Studies carried out in the past take into consideration mainly single research station or sources, the only exception being Boutron and Wolff (1989), who suggested sulfur emissions from fuel and waste burning of $70 \mathrm{Mg} / \mathrm{year}$ for 1987. Here, we attempt a full survey of contemporary anthropogenic emissions in Antarctica.

Global emission inventories like GEIA (Global Emission Inventory Activity), EDGAR (Emission Database for Global Atmospheric Research) etc. have been developed in the past to estimate the contributions of anthropogenic and natural sources towards the levels of different chemical species and greenhouse gases over national/regional/global scales. These databases are of great importance to climate modellers and atmospheric scientists who wish to understand the trends and spatio-temporal distribution of chemical species in the atmosphere and deposition at the surface. Besides this, as pointed by Buron et al. (2005), implications of these emission inventories arise for designing policies oriented towards reduction of emissions, especially from anthropogenic sources. However, so far the "pristine" Antarctic continent has not been included in these inventories.

This study presents a comprehensive emission inventory of $\mathrm{SO}_{2}$ emitted due to all anthropogenic activities in Antarctica for the one-year period 2004-2005. Human activities in Antarctica include power/heat generation at the research base, vehicular activity, marine and air-borne traffic. Use of diesel/gas oil in generators leads to the release of chemical species that might affect the air-quality in the vicinity of the bases. Vehicles are used for delivering fuel, support personnel and for carrying out scientific activities across Antarctica. Combustion of fuel in ship engines could lead to release of different pollutants along ship tracks and along coastal regions which might later get transported to elsewhere. Therefore, it becomes necessary to quantify the emissions from shipping operations as they tend to affect the environment especially through radiative forcing (e.g., Lawrence and Crutzen, 1999; Endresen et al., 2003) and are likely to be the most polluting source, particularly when compared to vehicle emissions. Aviation is also an important anthropogenic source of pollution (Tremmel et al., 1998), because the emissions are released directly into the sensitive area of the atmosphere (Kesgin, 2006), where other anthropogenic emissions are absent (Kjellstrom et al., 1999). Recent experimental studies on contamination of the atmosphere by emissions from aircraft engines during Landing and Take-off cycle (LTO) have been performed by Kesgin (2006). Here, the author mentions how an increase or decrease in LTO cycle timings could lead to consequent change in the emission of chemicals.

Besides anthropogenic emission sources there are also other sources contributing towards chemicals in the Antarctic environment. Oppenheimer et al. (2005) in their 2004 studies report approximately $2229 \mathrm{Mg} /$ month of $\mathrm{SO}_{2}$ and $155 \mathrm{Mg} /$ month of $\mathrm{NO}_{2}$ from Mt. Erebus volcano (point source) located on the Ross Island region of Antarctica.

Wang et al. (2007) estimate an average emission flux rate of $0.25 \mathrm{~kg} \mathrm{~N} \mathrm{~km}^{-2}$ month $^{-1}$ during December 2003 from snow-pack emissions over the plateau region $(2.5 \mathrm{~km}$ elevation) of Antarctica. Investigations by Minikin et al. (1998) reveal an annual mean concentration of methanesulfonate and sulphate from 3 different coastal Antarctic stations to be 38 and $151 \mathrm{ngm}^{-3}$ at Neumayer (1983-1995) and 20 and $147 \mathrm{ngm}^{-3}$ at Dumont d'Urville (1991-1995) and 15 and $50 \mathrm{ngm}^{-3}$ at Halley (1991-1992).

Penguin colonies present mostly at the peninsular sites are a source of non-marine biogenic (i.e. non DMS) sulphur in the Antarctic environment and account for approximately $5.5 \times 10^{-5} \mathrm{nmol} \mathrm{m}^{-3}$ of sulphur on a per-penguin basis (Xie et al., 2002). This amounts to $\sim 279 \mathrm{nmol} \mathrm{m}^{-3}$ of sulphur from all the penguin rookeries spread across the Antarctic continent and surrounding islands. An emission inventory for these sources excluding the Mt. Erebus volcano has not been constructed but should be considered in the context of anthropogenic emissions.

The present research suggests a technique for designing emission inventories for anthropogenic activities in Antarctica using certain logical assumptions. These emission data will in the future be included in a regional climate chemistry model, REMOTE (Regional Model with Tracer Extension) (Langmann, 2000), used widely in Europe and beyond to investigate atmospheric composition, transport and surface deposition. Assumptions had to be made on the basis of limited information available from research bases operating in Antarctica, through personal communication and COMNAP (Council of Managers for National Antarctic Program). Earlier works by Boutron and Wolff (1989) provided an inventory of heavy metal and sulphur emissions due to anthropogenic activities in Antarctica and proposed that these emissions could severely impact snow/air concentrations in localized areas.

Certain vital factors have to be considered while preparing emission inventories of any combustion source, whether stationary or mobile (Corbett and Koehler, 2003). Firstly, estimates of fuel consumption for each anthropogenic activity are made using available fuel consumption information and extrapolation is applied for sources (vehicles, ship) whose information is not obtainable. Secondly, the fluxes of chemicals are computed by multiplying the fuel consumption estimates with the density of fuel, emission factor and operating time depending on the type of emission source. Finally, the chemical species emitted from each source are assigned to 
Table 1. Emission factor of Sulfur dioxide for different types of fuel. These emission factors are taken from NAEI.

\begin{tabular}{lr}
\hline Emission Source & Emission factors \\
\hline Generators (Gas oil) & $3.25 \mathrm{e}^{-3}$ \\
Generators (diesel fuel) & $33 \mathrm{e}^{-3}$ \\
Vehicles (Principally ATF) & $1.0 \mathrm{e}^{-7}$ \\
Marine gas oil (for ships) & $1.9 \mathrm{e}^{-2}$ \\
Fuel oil (for ships) & $5.2 \mathrm{e}^{-2}$ \\
Aviation Turbine fuel & $7.2 \mathrm{e}^{-4}$ \\
(for International Flights) & \\
Aviation turbine fuel & $7.2 \mathrm{e}^{-4}$ \\
(for Domestic Flights) & \\
\hline
\end{tabular}

the location of the emissions, according to the type of operation. The emission inventory consisting of flux rates of $\mathrm{SO}_{2}$ and $\mathrm{BC}$ from anthropogenic activities in Antarctica are calculated using the above technique. However, we only present an emission inventory of $\mathrm{SO}_{2}$ in the present study. A similar procedure could be applied for calculating and designing an inventory for any chemical species. The emission maps of $\mathrm{SO}_{2}$ produced using the fluxes, indicate the intensity and localisation of human activity in Antarctica during each month. We will first describe how we arrive at the flux rates of sulphur for the different source types and then present emission maps for single months of the year under study. The data are stored on a $50 \mathrm{~km} \times 50 \mathrm{~km}$ grid and will later be used as input for a regional climate chemistry model, REMOTE to calculate atmospheric concentrations and deposition rates.

\section{Emission inventory}

In this section, the methodology adopted to prepare the emission inventory (input data) of different anthropogenic sources in Antarctica for the period 2004-2005 is described. Important parameters required to calculate the flux rate of chemical species are a) estimate of fuel consumed, b) density of fuel and c) emission factor. The emission factor is defined as a representative value that relates the quantity of pollutant released into the atmosphere with an activity associated with the release of that pollutant. Thus, a particular species may have different emission factors depending on the type of fuel and the kind of activity. Table 1 shows a list of emission factors available from NAEI (National Atmospheric Emission Inventory, 2000) and used for the present study.

As seen in Table 1, the emission factors vary with the type of fuel associated with a particular kind of activity. We calculate the flux rate of chemical species by multiplying the amount of fuel consumed with the density of fuel and the appropriate emission factor, using Eq. (1). Where "FR" denotes the flux of chemical species in $\mathrm{kg} / \mathrm{month}$, " $Q$ " the amount of fuel consumed in $\mathrm{m}^{3} /$ month, " $\rho$ " the density of fuel in $\mathrm{kg} / \mathrm{m}^{3}$,
Table 2. List of 9 research bases with available fuel information.

\begin{tabular}{llll}
\hline Research base & Country & Latitude & Longitude \\
\hline Bird Island & UK & $54^{\circ} \mathrm{S}$ & $38^{\circ} 03^{\prime} \mathrm{W}$ \\
Casey & Australia & $66^{\circ} 17^{\prime} \mathrm{S}$ & $110^{\circ} 31.18^{\prime} \mathrm{E}$ \\
Davis & Australia & $68^{\circ} 34.63^{\prime} \mathrm{S}$ & $77^{\circ} 58.35^{\prime} \mathrm{E}$ \\
Halley & $\mathrm{UK}$ & $75^{\circ} 34.9^{\prime} \mathrm{S}$ & $26^{\circ} 32.47^{\prime} \mathrm{W}$ \\
King Edward Point & $\mathrm{UK}$ & $54^{\circ} 17^{\prime} \mathrm{S}$ & $36^{\circ} 30^{\prime} \mathrm{W}$ \\
Maitri & India & $70^{\circ} 45.95^{\prime} \mathrm{S}$ & $11^{\circ} 44.15^{\prime} \mathrm{E}$ \\
Mawson & Australia & $67^{\circ} 36.28^{\prime} \mathrm{S}$ & $62^{\circ} 52.25^{\prime} \mathrm{E}$ \\
Rothera & UK & $67^{\circ} 34.17^{\prime} \mathrm{S}$ & $68^{\circ} 7.20^{\prime} \mathrm{W}$ \\
Troll & Norway & $72^{\circ} 12^{\prime} \mathrm{S}$ & $2^{\circ} 32.03^{\prime} \mathrm{E}$ \\
\hline
\end{tabular}

"EF" the Emission factor, $i$ represents the type of fuel, $j$ represents the type of emission source and $k$ the type of chemical species, then

$\mathrm{FR}(i, j, k)=Q * \rho(i) * \operatorname{EF}(i, j, k)$

The emission inventory is constructed by assigning the flux rate of chemical species at the appropriate location of emission.

\subsection{Power/heat generation at research bases}

Power/heat generation forms one of the major activities at all research stations, inevitably resulting in the emission of chemicals. The inventory is designed on the basis of the emission rate of chemical species and depends on a number of factors. For example (a) number of generator sets, (b) amount of fuel and (c) type of fuel used by these generator sets. Generators used at most of these bases burn diesel fuel or gas oil. Initially, information about fuel consumption for power/heat generation was only obtained from 9 out of 53 research bases through personal communication and literature survey. The list of these 9 bases is shown in Table 2 .

The data available from these 9 research stations are the total amount (litres per year) and type of fuel consumed by generators for heating. The fuel consumption is approximately the same during a particular season (summer/winter), but might vary for each season depending on the intensity of activity and number of people present at the base. Therefore, the approach adopted to estimate the fuel consumption per summer/winter month is based on the number of people present at the base (i.e. per-capita). Thus,

$F=F_{s}+F_{w}$

$F_{s}=F / N * N_{s}$ and $F_{w}=F / N * N_{w}$

$F_{s m}=F_{s} / 5$ and $F_{w m}=F_{w} / 7$

where $F$ is the total amount of fuel used per year in $\mathrm{m}^{3}, F_{s}$ and $F_{w}$ is the fuel consumed during summer and winter, $N$ is the total human population at a research base during a year, 


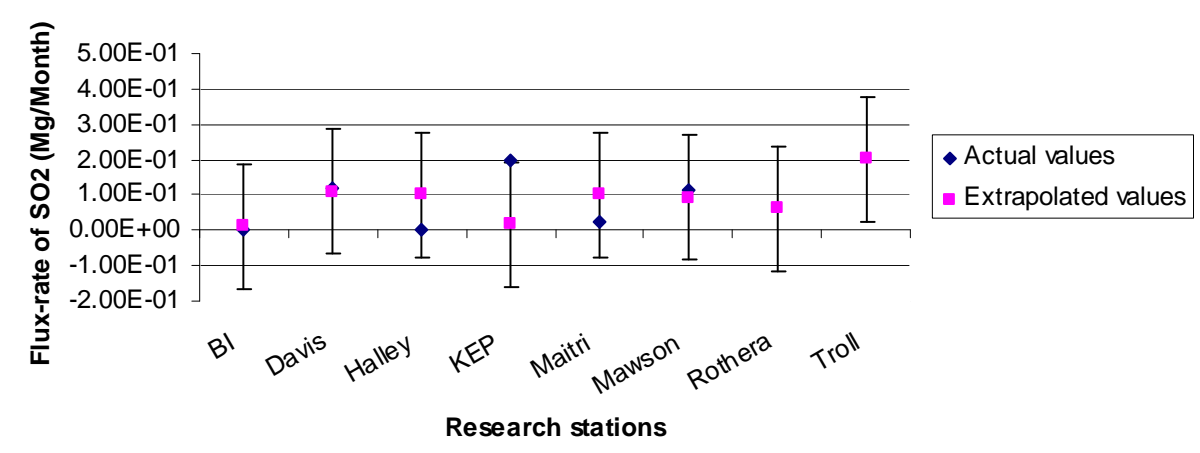

Fig. 1. Comparison of extrapolated (pink) versus actual (blue) $\mathrm{SO}_{2}$ emission flux-rate from power/heat generation, when extrapolated from best choice "Casey".

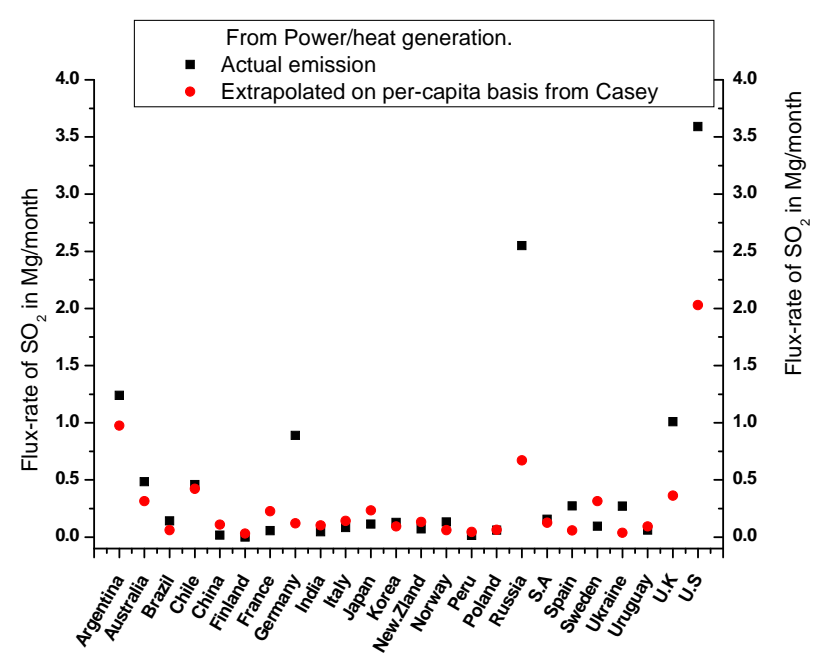

Nations operating research stations in Antarctica

Fig. 2. Comparison of the flux rates of $\mathrm{SO}_{2}$ from power/heat generation only, actual (black) versus extrapolated on per-capita basis (red).

$N_{s}$ and $N_{w}$ is the summer and winter population at the research base, $F_{s m}$ and $F_{w m}$ is the fuel consumed during each summer and winter month. The summer and winter season is considered from November to March (5 months) and April to October (7 months), respectively. To obtain the actual flux rate of the required chemical species, the fuel consumption per month is multiplied with fuel density and appropriate emission factors as in Eq. (1) for all the 9 research bases. Since inadequate information is available for the remaining 44 bases, it is required to extrapolate their information (percapita basis) from one "best" base out of the 9 research bases with a full data set.

To assess the quality of extrapolation and to select a "best" base from a pool of 9 , one base is taken out and on percapita basis the fuel consumption is linearly extrapolated to the other 8 bases. The extrapolated fuel consumption val- ues are converted into emission flux rates using Eq. (1). This process is repeated for all the 9 bases and the mean error is calculated by comparing the actual and extrapolated emission flux rates in terms of $\mathrm{SO}_{2}$ (as shown in Fig. 1) for the Casey research station, which turned out to be the best choice for estimating unknown fuel consumed.

The approximate mean error when extrapolated from each of the 9 research bases is 0.1745 (Casey), 0.176 (Davis), 0.177 (Mawson), 0.2178 (Bird-Island), 0.2126 (Maitri), 0.2303 (Halley), 0.2403 (Rothera), 0.7438 (Troll) and 1.064 (King Edward point). Based on this check Casey is chosen for extrapolating the fuel consumption values to the remaining 44 research bases, without fuel consumption information. Only later, fuel consumption estimates for power/heat generation for almost all the 44 research bases was obtained from the COMNAP website. The information available at COMNAP consists of the type and amount of fuel used for power generation during a particular year and this data is converted into fuel consumed per month using Eqs. (2), (3) and (4). The actual emission rate of chemical species is then calculated using Eq. (1), while per-capita scaling from Casey is also performed to obtain the extrapolated emission flux rate for all 44 research bases. Figure 2 shows emission flux-rates from both per capita estimated and actual fuel consumption at the stations based on nations, i.e. not for individual stations. It shows that the extrapolated emission flux rate ( $\mathrm{Mg} / \mathrm{Month})$ of $\mathrm{SO}_{2}$ from Casey research base corresponds fairly well with the actual values for most of the countries research bases, except for a few where it either underestimates or overestimates. An underestimation by per-capita fuel use, exceeding the extrapolated value by approximately a factor of 7, 4, 3 and 2 is found for the bases operated by Germany, Russia, UK and US nations, respectively. The possible reason for this under-estimation could be that weather conditions at Kohnen (Germany), Vostok (Russia), Halley (UK) and Amundsen-Scott (USA) bases could lead to an increase in fuel consumption for power/heat generation at the base sites. Though population-size largely affects the emission of chemical species from a particular base, other factors like human 
Table 3. List of research bases with available fuel information for vehicles.

\begin{tabular}{llll}
\hline Research base & Country & Latitude & Longitude \\
\hline Amundsen-Scott & USA & $89^{\circ} 59.85^{\prime} \mathrm{S}$ & $139^{\circ} 16.37^{\prime} \mathrm{E}$ \\
Bird Island & UK & $54^{\circ} \mathrm{S}$ & $38^{\circ} 03^{\prime} \mathrm{W}$ \\
Casey & Australia & $66^{\circ} 17^{\prime} \mathrm{S}$ & $110^{\circ} 31.18^{\prime} \mathrm{E}$ \\
Concordia & France/Italy & $75^{\circ} 06.12^{\prime} \mathrm{S}$ & $123^{\circ} 23.72^{\prime} \mathrm{E}$ \\
Davis & Australia & $68^{\circ} 34.63^{\prime} \mathrm{S}$ & $77^{\circ} 58.35^{\prime} \mathrm{E}$ \\
Dumont dUrville & France & $66^{\circ} 39.77^{\prime} \mathrm{S}$ & $140^{\circ} 0.08^{\prime} \mathrm{E}$ \\
Gabriel Castilla & Spain & $62^{\circ} 59^{\prime} \mathrm{S}$ & $60^{\circ} 41^{\prime} \mathrm{W}$ \\
Halley & UK & $75034.9^{\prime} \mathrm{S}$ & $26^{\circ} 32.47^{\prime} \mathrm{W}$ \\
Juan Carlos Primerio & Spain & $62^{\circ} 39^{\prime} \mathrm{S}$ & $60^{\circ} 23^{\prime} \mathrm{W}$ \\
King Edward Point & UK & $54^{\circ} 17^{\prime} \mathrm{S}$ & $36^{\circ} 30^{\prime} \mathrm{W}$ \\
Maitri & India & $70^{\circ} 45.95^{\prime} \mathrm{S}$ & $11^{\circ} 44.15^{\prime} \mathrm{E}$ \\
Mario Zucchelli & Italy & $74^{\circ} 41^{\prime} \mathrm{S}$ & $164^{\circ} 07^{\prime} \mathrm{E}$ \\
Mawson & Australia & $67^{\circ} 36.28^{\prime} \mathrm{S}$ & $62^{\circ} 52.25^{\prime} \mathrm{E}$ \\
McMurdo & U.S.A & $77^{\circ} 50.88^{\prime} \mathrm{S}$ & $166^{\circ} 40.10^{\prime} \mathrm{E}$ \\
Rothera & U.K & $67^{\circ} 34.17^{\prime} \mathrm{S}$ & $68^{\circ} 7.20^{\prime} \mathrm{W}$ \\
SANAE & S.A & $71^{\circ} 40.42^{\prime} \mathrm{S}$ & $2^{\circ} 49.73^{\prime} \mathrm{W}$ \\
Scott & New Zealand & $77^{\circ} 51.00^{\prime} \mathrm{S}$ & $166^{\circ} 45.77^{\prime} \mathrm{E}$ \\
Troll & Norway & $72^{\circ} 12^{\prime} \mathrm{S}$ & $2^{\circ} 32.03^{\prime} \mathrm{E}$ \\
Wasa & Sweden & $73^{\circ} 03^{\prime} \mathrm{S}$ & $13^{\circ} 25^{\prime} \mathrm{W}$ \\
\hline
\end{tabular}

activities, type and number of generator-sets used, quality and quantity of fuel, weather conditions etc., could possibly be the cause of differences between the actual and extrapolated values. As we have no information about the causes of this, we cannot comment further. However, Fig. 2 clearly suggests that in case of insufficient fuel information, a linear extrapolation on the basis of population can be used as a tool to calculate the emission of chemical species from anthropogenic activities in areas where there is a paucity of information.

\subsection{Vehicles}

Vehicles are one of the common modes of transport essential for delivering fuel and support personnel to different places within Antarctica. The important requirements for preparing an emission inventory of chemicals from road transport is the type and amount of fuel consumed by the vehicles, the number of operating hours and the total distance traversed by these vehicles during any period.

Data on vehicle operations in Antarctica were obtained from 19 out of 53 research bases through literature research and personal communication. The list of these 19 bases is shown in Table 3. This data contained information on a) number of operating hours of vehicles, b) distance travelled (kilometres), c) fuel consumed (in Litres/hour), d) number of vehicles and e) type of vehicle operations. For the remaining 34 bases only information on type and number of vehicles is available from COMNAP. Due to a lack of information from the 34 research bases, the vehicle fuel consumption for these bases is extrapolated from vehicular fuel consumption estimates at Casey (Australia), based on the assumption that fuel consumption per vehicle of a particular type is similar at all stations. Besides this, from the AAD (Australian Antarctic Division) website and the scientific activity reports (Report of the Committee for Environmental Protection, CEP IX, 2006) it is found that Casey base has a proper logistic management system and uses adequate quantity of fuel for different activities with minimum fuel spills. This is the best guess that could be made from the restricted information available.

Because most of the vehicles operating at research bases in Antarctica use diesel, the total flux rate of chemical species from each vehicle is calculated as shown in Eq. (5). Since vehicles rarely operate during winter in Antarctica the emission flux rate is calculated only for summer months.

$\mathrm{FR}(i, j, k)=Q * \tau * \rho(j) * \mathrm{EF}(i, j, k)$

Where $\tau$ represents the number of operating hours.

The emission inventory is constructed by assigning the flux rate of chemicals from power generation at research stations to the grid-cell $(55 \times 55 \mathrm{~km})$ of REMOTE, which corresponds to the geographic location (latitude, longitude, altitude) of the research base. For vehicles, this is done by splitting the emission flux rate between the research bases and surrounding areas depending on the type of vehicle and its operations. For example, if Station A has different types of vehicles like rough terrain vehicles, tractors, excavators, motor vehicles, snow-mobiles etc, then the actual grid cell position of Station A would receive an emission flux rate from power generation and operation of all the vehicles present at the base, while the surrounding 8 grid cells would receive an 

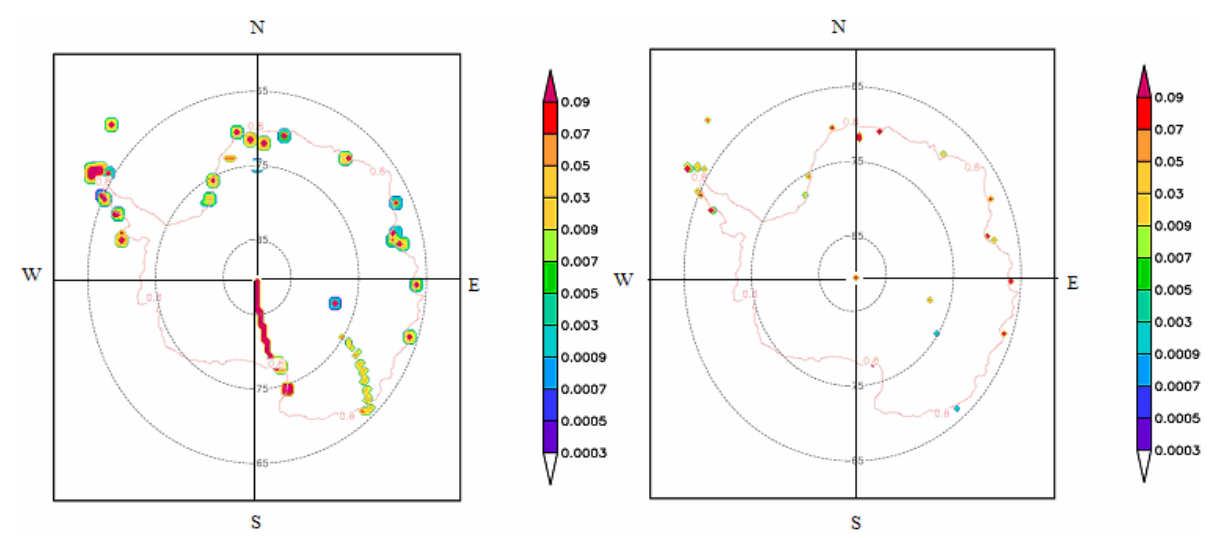

Fig. 3. An emission inventory map of $\mathrm{SO}_{2}$ (in $\mathrm{Mg} / \mathrm{Month}$ ) from power generation and vehicles operating at research bases during (a) summer and (b) winter of 2004-2005. The map of Antarctica is obtained using land-sea mask (seen as contour lines). The concentric circles and straight lines represent latitude and longitude zones.

emission flux rate from operation of only small vehicles like snow-mobiles, motor vehicles. Besides this, if there is any traverse operation from Station A to another station, then the emissions are assigned along the path of travel of the vehicles.

An inventory depicting the emission flux rate of $\mathrm{SO}_{2}$ (in $\mathrm{Mg}$ /month) from human activities in and around the base during a typical summer and a winter month is shown in Fig. 3. Because human activity at a particular base remains almost the same during a season (summer/winter) but is different for each season, only one inventory map representing the summer/winter months is shown for each season.

The approximate total flux of $\mathrm{SO}_{2}$ from power generation and vehicles for summer and winter month is 26 and $4 \mathrm{Mg} / \mathrm{month}$, respectively. The emission rate of $\mathrm{SO}_{2}$ in winter is less than for summer because of low occupation at almost all the research bases, therefore leading to less total use of fuel for power generation or melting water for consumption. Besides this, some of the research bases operate during summer only and there is very little or no vehicular activity at almost all the research bases during winter.

The total estimated yearly emission of $\mathrm{SO}_{2}$ from power generation and vehicles during 2004-2005 (April 2004March 2005) is approximately $158 \mathrm{Mg} /$ year. This does not include open burning of waste as this is prohibited according to the Environmental/Madrid Protocol which came into force in 1998. Earlier studies by Boutron and Wolff (1989) suggested that the flux of sulphur from fuel and waste burning at research stations in Antarctica in 1987 was $70 \mathrm{Mg}$ /year. The difference likely reflects that human activities have intensified. We are not aware of any other estimates of flux of $\mathrm{SO}_{2}$ due to human activities in Antarctica.

\subsection{Ships}

Ships represent the world's highest polluting combustion sources per quantity of fuel consumed (Corbett and Fishbeck, 1997). Preparing an inventory of chemical species emitted from ships is one of the crucial tasks as these inventories demonstrate the significance of ship emissions in assessing environmental impacts of atmospheric pollution. Important parameters required for constructing such inventory are: a) list of ships (cruise + research), b) travel route, c) number of days of cruise/mooring, d) sea-ice conditions, e) type of fuel and f) amount of fuel consumed. Recently, fishing in the Southern Ocean during southern-hemisphere summer has been an important activity by vessels. As mentioned in CCAMLR (Commission for Conservation of Antarctic Marine Living Sources) scientific committee reports (Report of the XXIII and XXIV meeting of the scientific committee, 2004 and 2005), during 2003-2004 summer 20-30 ships belonging to different nations fished in Antarctic waters, which dropped to 10-20 during summer 2004-2005. The major areas being fished are South Georgia $\left(54^{\circ} \mathrm{S}, 38^{\circ} 03^{\prime} \mathrm{W}\right)$, Kerguelen Islands $\left(49^{\circ} 15^{\prime} \mathrm{S}, 69^{\circ} 35^{\prime} \mathrm{E}\right)$, Heard Island $\left(53^{\circ} 06^{\prime} \mathrm{S}, 73^{\circ} 31^{\prime} \mathrm{E}\right)$, Prince Edward Islands $\left(46^{\circ} 46^{\prime} 23^{\prime \prime} \mathrm{S}, 37^{\circ} 56^{\prime} 36^{\prime \prime} \mathrm{E}\right)$ and Crozet Islands $\left(46^{\circ} 25^{\prime} \mathrm{S}\right.$, $51^{\circ} 59^{\prime} \mathrm{E}$ ). Due to the unavailability of adequate information regarding fishing vessels in Antarctic waters and because the fishing areas lie just outside the REMOTE model domain, they have not been considered in the current research.

Information on research and cruise ships is obtained via personal communication and literature research or for those research ships whose information is not made available, with an online philately (Antarctic New-Zealand philately). This source provides information for philatelists who collect stamped envelopes which bear the name of the research vessel, port of embarkment/disembarkment and tentative date of travel of these ships. We think that this is a rather 
unusual but nevertheless reliable source of information. The data obtained through personal communication contains information on fuel consumption during the entire travel period, number of days of travel/mooring and port of embarkment/disembarkment. Information about cruise vessels was obtained from IAATO. This contains only the name, detailed itinerary and passenger carrying capacity of the ship. Due to scarce information on fuel consumption by research and cruise ships, data from research ships belonging to the same country was used and extrapolated according to the configuration of the ship. During summer 2004-2005 approximately $65 \%$ were cruise vessels. Some of the research vessels also carry tourists during their voyage to Antarctica. An emission inventory of ships was then constructed using the following steps.

1. Most of the ships travelling to Antarctica use Marine diesel oil or Marine gas oil and the total flux rate of chemical species is calculated according to Eq. (1).

2. The ship tracking system available online is used for locating the track of ships (research/cruise) from different regions to sites within Antarctica. Sea ice (SI) maps are used to locate areas covered with SI or open ocean (OO).

3. To distribute the emission flux rate from ships in SI/OO, we divide the total flux rate by the total number of position points along a ship track. Since the density of position points of the ship in SI is higher, their emission per nautical mile is higher than in OO. It is assumed that the flux rate of chemicals from ships mooring at Antarctic ports is half of its actual emission in $\mathrm{OO}$ because the engines operate only to keep the electric supply within the ship in an ON state. This is the most reasonable assumption we could make for purposes of simplification and because of unavailability of accurate information on fuel consumption by ships in SI, OO or ports.

4. An emission inventory is prepared by assigning the flux rate of chemical species at the 0.5 degree grid-cell position of REMOTE, which corresponds to the geographic location of emission, depending on the track of the ships.

The emission inventory for ships is prepared for each summer month (November-March) of 2004-2005 only since ships do not travel during Antarctic winters. A typical inventory map of $\mathrm{SO}_{2}$ is shown in Fig. 4. Similar maps can also be obtained for other chemical species knowing their emission rates.

Corbett and Koehler (2003) estimated an annual flux of $4.72 \mathrm{Tg}(\mathrm{S})$ from all ocean going ships for the 2001 fleet activity. The total $\mathrm{SO}_{2}$ emitted by ships travelling to Antarctica during November-March 2004/05 is 223, 1971, 769, 693, $217 \mathrm{Mg} /$ month, indicating December as the busiest period of shipping activity. The sum of calculated emissions for this study gives a total of $3873 \mathrm{Mg}$ of $\mathrm{SO}_{2}$ (November 2004March 2005). This estimate is only a small fraction of the global sulfur emissions from ocean ships, less than $0.1 \%$, but more than a factor of 10 above the combined research station emissions. These maps also suggest that the peninsular region and the Sub-Antarctic Islands remain the most visited areas by ships, especially the tourist vessels and form the locus maximus of shipping activity. The research ships mostly visit stations owned by the respective nations located at peninsular sites and the tourist ships visit various peninsular sites and Sub-Antarctic Islands for tourism and recreation purpose.

\subsection{Aircraft}

Designing an inventory for aircraft emissions requires certain important factors to be taken into account. The emission inventory of aircraft operating in Antarctica is constructed by considering the a) travel route, b) number of flights during a particular month, c) operational times during LTO cycle, d) fuel flow during each operation time and e) emission factors of each chemical species. A typical LTO cycle described by the International Civil Aviation Organisation (ICAO) (Penner et al., 1999) is shown in Fig. 5.

The different modes of operation during the LTO cycle include take-off, climb, approach and cruise. In this study, we have considered the time for approach, taxi, take-off and climb from a standard LTO cycle; i.e. 4 min for approach, $26 \mathrm{~min}$ for taxi, $0.7 \mathrm{~min}$ for take-off and $2.2 \mathrm{~min}$ for climb (Penner et al., 1999).

Crude data on travel route, number of flights (intercontinental and intra-continental) and fuel consumption by aircraft operations in Antarctica is obtained from COMNAP, literature research and through personal communication. To calculate the flux rate (per month) of chemicals, we multiply the fuel flow during each operational mode with density of fuel, total number of flights and emission factor, as shown in Eq.(6).

$\mathrm{FR}(i, j, k)=\mathrm{FF}(m) * N_{f} * \rho(j) * \mathrm{EF}(i, j, k)$

Where $\mathrm{m}$ represents the operational mode, FF represents the fuel flow during each operational mode and $N_{f}$ the total number of flights (per month).

The inventory of chemicals from aircraft is prepared by assigning the emission flux rate of chemical species to the REMOTE grid-cell position, corresponding to the position of the aircraft tracks. An emission inventory map of aircraft and cruise liners operating within the continent at cruise altitude (10 000 feet) during summer 2004-2005 is shown in Fig. 6.

The total emission flux rate during taxi, climb-out, approach and cruise for $\mathrm{SO}_{2}(\mathrm{Mg} /$ month) from November 2004-March 2005 is 6.36, 5.6, 21.27, 21.12, 1.28, showing January as the busiest period for aircraft operations in Antarctica. This adds up to approximately 56 Mega-grams of 

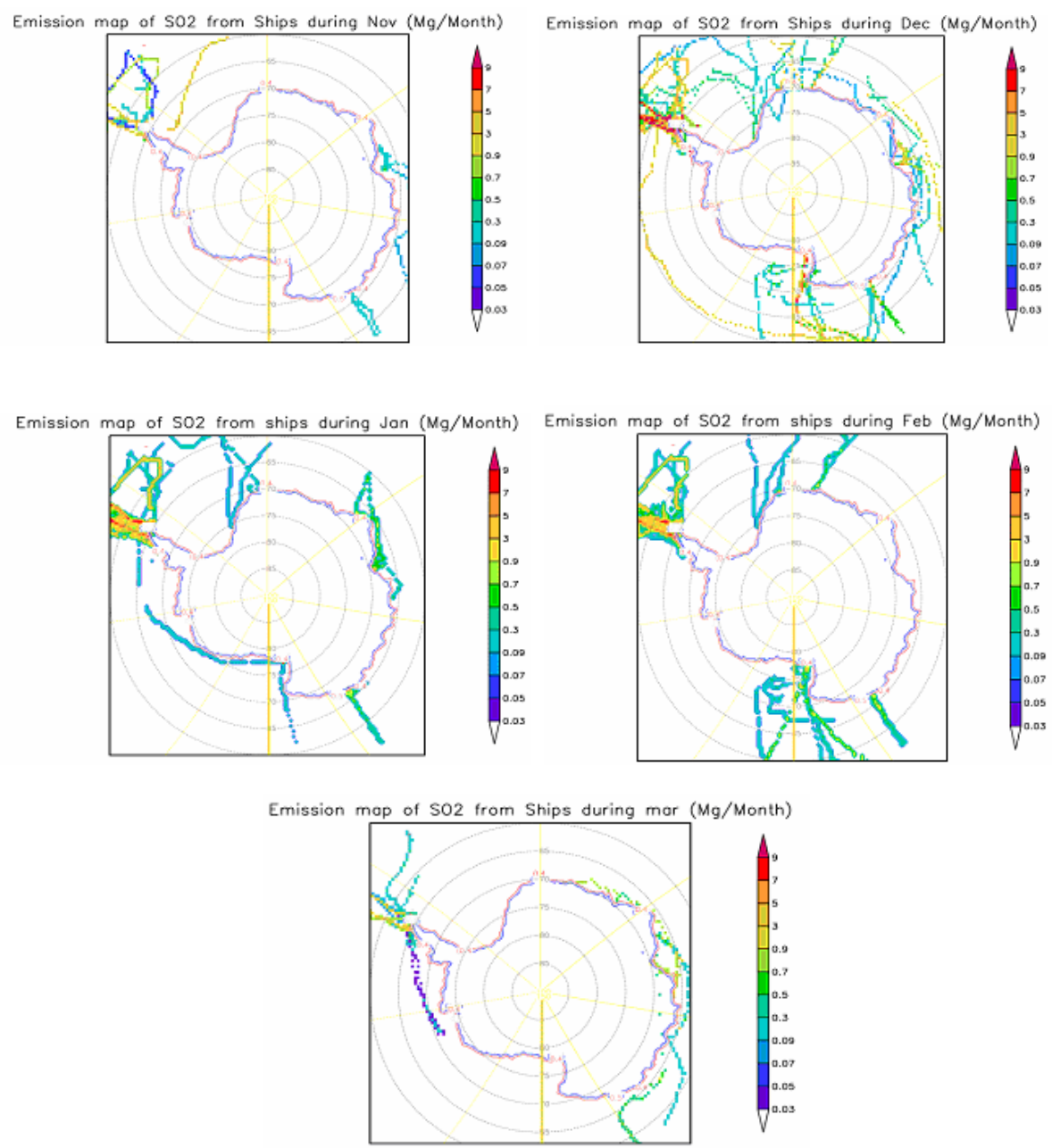

Fig. 4. Emission inventory map explaining the tracks of research and cruise ships to Antarctica and back, for November, December, January, February and March months of 2004-2005. The map of Antarctica is obtained from land-sea mask (seen as contour lines). The concentric circles and straight lines represent latitude and longitude zones.

$\mathrm{SO}_{2}$ for the above mentioned period, as very few or no flights operate during Antarctic winter. Kjellstrom et al. (1999), in their 1991/92 study estimate $0.056 \mathrm{Tg}(\mathrm{S}) /$ year from global aircraft fleet or $0.112 \mathrm{Tg} \mathrm{SO}$. Hence, the total $\mathrm{SO}_{2}$ emissions from aircraft operations in Antarctica for NovemberMarch $2004 / 05$ is $0.05 \%$ of the $1991 / 92$ global annual $\mathrm{SO}_{2}$ emissions from aircraft fleet. These values are low when compared with station activity and are exceeded by ship emissions by two orders of magnitude.

Besides $\mathrm{SO}_{2}$, chemicals like $\mathrm{CO}_{2}, \mathrm{CO}, \mathrm{Hg}, \mathrm{Pb}$ etc. are also emitted from anthropogenic activities in Antarctica. Using the fuel consumption values and emission factors for each anthropogenic activity the total emission flux for $\mathrm{CO}_{2}, \mathrm{CO}$, $\mathrm{Hg}$ and $\mathrm{Pb}$ is calculated and shown in Table 4.

It should be emphasised here that the flux of $\mathrm{CO}_{2}, \mathrm{CO}$, $\mathrm{Hg}, \mathrm{Pb}$ (refer Table 4) and $\mathrm{SO}_{2}$ (refer Sect. 2.1, 2.2, 2.3 and 2.4) estimated from each anthropogenic activity in Antarctica are the best estimates based on the known fuel consumption
Table 4. Estimates of $\mathrm{CO}_{2}, \mathrm{CO}, \mathrm{Hg}$ and $\mathrm{Pb}$ from each anthropogenic emission source from this study.

\begin{tabular}{|c|c|c|c|c|}
\hline Activity & $\begin{array}{c}\mathrm{CO}_{2} \\
\text { (all units } \\
\text { in } \mathrm{Mg} / \text { year) }\end{array}$ & $\mathrm{CO}$ & $\mathrm{Hg}$ & $\mathrm{Pb}$ \\
\hline \multicolumn{5}{|l|}{$\begin{array}{l}\text { Power/heat } \\
\text { generation }\end{array}$} \\
\hline and vehicles & $11 \times 10^{3}$ & 24 & 0.00015 & 0.0008 \\
\hline Shipping & $13 \times 10^{4}$ & 1119 & 0.0034 & 0.073 \\
\hline Aircrafts & 66900 & 855 & $7.7 \mathrm{e}^{-7}$ & 0.0043 \\
\hline Total & 207900 & 1998 & 0.00355 & 0.0781 \\
\hline
\end{tabular}


Table 5. Comparison of $\mathrm{SO}_{2}$ emissions from different parts of the world.

\begin{tabular}{|c|c|c|c|c|}
\hline Source & Region & $\begin{array}{l}\text { Category: } \\
\text { Emission }\end{array}$ & Base year & Reference \\
\hline $\begin{array}{l}\text { Only Power generation } \\
\text { and Transportation. }\end{array}$ & USA & $\begin{array}{l}15.477 \mathrm{Tg} / \text { year of } \\
\mathrm{SO}_{2}\end{array}$ & 1990 & $\begin{array}{l}\text { EDGAR emission } \\
\text { inventory }\end{array}$ \\
\hline $\begin{array}{l}\text { Only Power generation } \\
\text { and Transportation. }\end{array}$ & W. Europe \& E. Europe & $\begin{array}{l}9.634 \text { and } \\
6.911 \mathrm{Tg} / \text { year of } \\
\mathrm{SO}_{2}\end{array}$ & 1990 & $\begin{array}{l}\text { EDGAR emission } \\
\text { inventory }\end{array}$ \\
\hline $\begin{array}{l}\text { Only Power generation } \\
\text { and Transportation. }\end{array}$ & China & $\begin{array}{l}7.871 \mathrm{Tg} / \text { year of } \\
\mathrm{SO}_{2}\end{array}$ & 1990 & $\begin{array}{l}\text { EDGAR emission } \\
\text { inventory }\end{array}$ \\
\hline $\begin{array}{l}\text { Natural and } \\
\text { Anthropogenic. }\end{array}$ & Norilsk & $\begin{array}{l}1.2 \mathrm{Tg} / \text { year of } \mathrm{S} \text { or } \\
2.4 \mathrm{Tg} / \text { year of } \\
\mathrm{SO}_{2}\end{array}$ & 1990 & Heidam et al., 1999 \\
\hline $\begin{array}{l}\text { Natural and } \\
\text { Anthropogenic. }\end{array}$ & Kola Peninsula & $\begin{array}{l}0.4 \mathrm{Tg} / \text { year of } \mathrm{S} \text { or } \\
0.8 \mathrm{Tg} / \text { year of } \mathrm{SO}_{2}\end{array}$ & 1990 & Heidam et al., 1999 \\
\hline $\begin{array}{l}\text { Power generation \& } \\
\text { Transportation }\end{array}$ & Antarctica & $\begin{array}{l}0.004 \mathrm{Tg} / \text { year of } \\
\mathrm{SO}_{2}\end{array}$ & 2004-2005 & This study \\
\hline
\end{tabular}

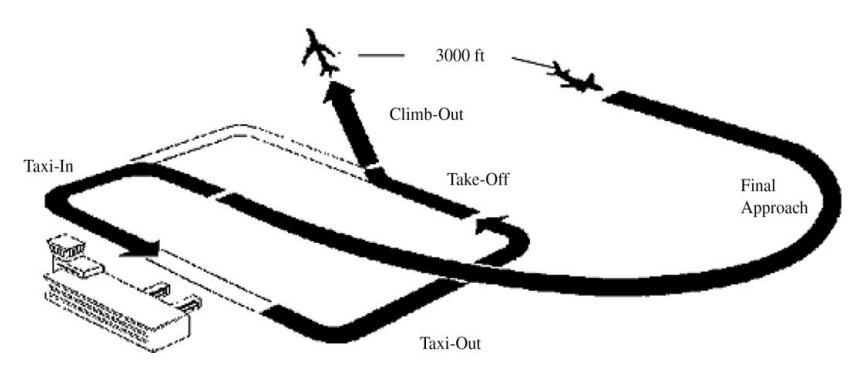

Fig. 5. LTO cycle as described by ICAO.

values and emission factors available from the literatures and NAEI. It is seen that $\mathrm{CO}_{2}$ released from anthropogenic sources mentioned above is the highest of all emissions. Although these and many other chemicals are released during anthropogenic operations in Antarctica, an emission inventory of $\mathrm{SO}_{2}$ only has been prepared by assigning the chemical specie at the grid cell position of the regional model (REMOTE) in order to examine the transport, distribution and deposition rates in future.

\subsection{Comparison of $\mathrm{SO}_{2}$ emissions from different parts of the world}

Comparison of $\mathrm{SO}_{2}$ fluxes from anthropogenic activities in Antarctica and other regions of the world has been done and is shown in Table 5.

As seen from Table 5, the $\mathrm{SO}_{2}$ flux from power generation and transportation (vehicle, ship and aircraft) in Antarctica during 2004-2005 is between 3-4 orders of magnitude less than the emissions from similar operations in US, Eu- rope and China, and between 2-3 orders of magnitude lower than emissions in Norilsk and Kola Peninsula for the 1990 period. High emission of sulphur in Norilsk and Kola Peninsula is because of non-ferrous smelters operating in these areas (AMAP report, 1998). The $\mathrm{SO}_{2}$ emission from transportation and power/heat generation in Antarctica is much lower because research stations and transportation majorly occurs during summer. During winter, because of harsh climatic conditions human population at the stations is comparatively less, with some stations temporarily shut down and no transportation occurring to or within the continent. However, these emissions are an indication of human presence within Antarctica and stand important when pristinity of the continent is concerned.

\section{Conclusions}

A thorough knowledge of the time-evolving details of different anthropogenic activities in Antarctica is essential for a variety of reasons: a) to be aware of the evolution of human presence in Antarctica, b) calculate the amount of emissions due to each anthropogenic activity for pollution studies, c) estimate the radiative forcing due to each chemical agent and d) provide an opportunity for policy-makers to regulate pollutant emissions. With the increasing human activity the terrestrial ecosystems of Antarctica are affected and this is seen by changes in vegetation and geographical ranges of several species (Olech, 1996). Human approach to nesting water birds like penguin colonies can intimidate them causing the nest contents to be spilled, exposed to predation and temporary or permanent abandonment (Carney et al., 1999). Besides this, scientists have found traces of soot, $\mathrm{PM}_{10}$, metals 

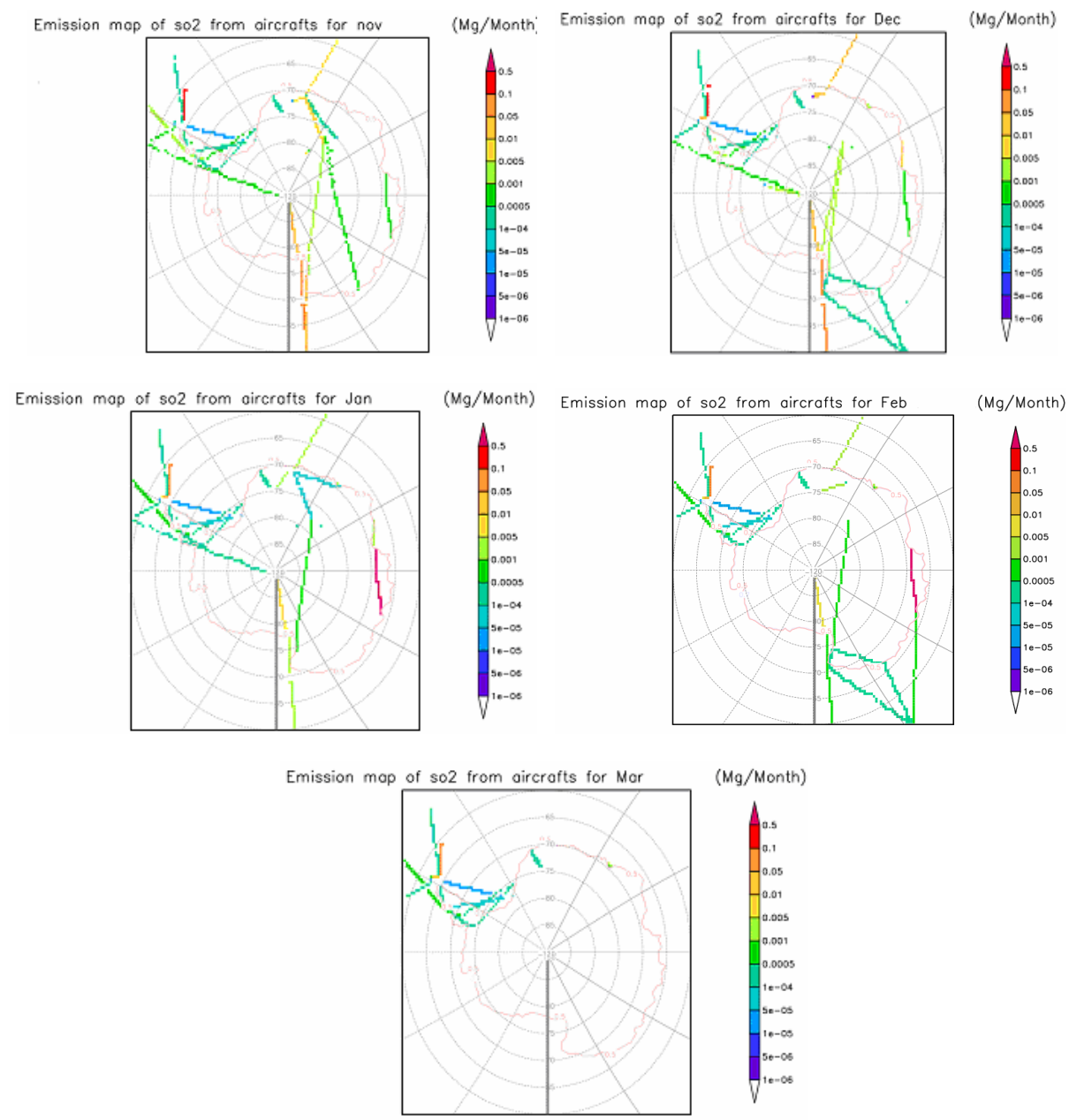

Fig. 6. Emission inventory map explaining the tracks of aircraft to Antarctica at Cruise altitude, for November, December, January, February and March months of 2004-2005. The map of Antarctica is obtained from land-sea mask (seen as contour lines). The concentric circles and straight lines represent latitude and longitude zones.

and various other chemicals in air and snow samples due to the anthropogenic activities occurring at the research stations and their vicinity (Mazzera et al., 2001).

This study demonstrates a feasible technique to design emission inventories of chemical species from anthropogenic sources in Antarctica for the 2004-2005 period and beyond using certain logical assumptions. The assumptions were made due to unavailability of sufficient information on fuel consumed for different anthropogenic activities from the countries owning research stations in Antarctica. Depending on the type of anthropogenic source, the flux rate of chemical species is calculated using Eqs. (1), (5) or (6). The results of $\mathrm{SO}_{2}$ emission flux rates from each anthropogenic source are presented here. The emission inventory maps give a picture of how the emissions are distributed over the Antarctic region during a particular month. The approximate flux of $\mathrm{SO}_{2}$ is $158 \mathrm{Mg} /$ year from power generation and vehicles, $3873 \mathrm{Mg} /$ year from ships and $56 \mathrm{Mg} /$ year from aircraft for the 2004-2005 period. The results show that shipping is the major contributor to pollutants in the Antarctic environment.

The estimated flux rates of chemical species, though still small compared with other regions of the world, might tend to be a source of local pollution in the pristine environment of Antarctica. This study recommends the concerned national operators to maintain and publish records of their yearly activities, so that a more realistic picture of the distribution of chemical species over Antarctica could be obtained. Finally, this research also has implications for policy making, especially concerning the growing trend of tourist visits to the continent.

The future work would be to execute the regional model REMOTE with the emission inventory of all anthropogenic sources and also including natural source like the permanent emissions from Mt. Erebus in order to understand the transport, distribution, deposition patterns and radiative forcing of chemicals from each source. 
Acknowledgements. We, take this opportunity to deeply acknowledge the efforts taken by Roderick Downie (British Antarctic Survey, Cambridge, UK), Anoop Tiwari (National Centre for Atmospheric and Oceanic Research, India), Birgit Njåstad (Norwegian Polar Institute, Norway), Richard Skinner (Department of Environment Affairs and Tourism, South Africa), Patrice Godon (French Polar Institute, France), Manual Catalan (Spanish Polar Committee, Spain), Johan Sidenmark (Swedish Polar research Secretariat, Sweden), Nino Cucinotta (National Antarctic Program of Italy, Italy) for providing us with the fuel consumption estimates for their respective scientific activities in Antarctica. We thank the Australian Antarctic division and the Antarctica New Zealand for making their scientific activity reports available. We also thank Jian Yang for helping us during the initial stages of our work. We are grateful to Clive Oppenheimer, (Dept. of Geography, University of Cambridge, UK) and Martin Jarvis (British Antarctic Survey, Cambridge, UK) for their valuable suggestions and comments. We are also thankful to two anonymous referees and reviewers for their valuable comments and suggestions.

Edited by: D. Cziczo

\section{References}

Andres, R. J., Marland, G., Fung, I., and Matthews, E.: A $1^{\circ} \times 1^{\circ}$ distribution of carbon dioxide emissions from fossil fuel consumption and cement manufacture, 1950-1990, Global Biogeochem. Cy., 10(3), 419-429, 1996.

Antarctic Philately from New-Zealand: online available at http:// www.newzeal.com/steve/antarctica.htm, January 2009.

Arctic Monitoring and Assessment Programme (AMAP), AMAP Assessment Report: Arctic Pollution Issues, Chapter 9: Acidifying Pollutants, Arctic Haze, and Acidification in the Arctic, Oslo, Norway, 1998

Australian Antarctica Division (AAD): online available at: http: //www.aad.gov.au/, Courtesy Australian Antarctic Division (C) Commonwealth of Australia, 2008.

Boutron, C. F. and Wolff, E. W.: Heavy metal and sulphur emissions to the atmosphere from human activities in Antarctica, Atmos. Environ., 23(8), 1669-1675, 1989.

Buron, J. M., Aparicio, F., Izquierdo, O., Gomez, A., and Lopez, I.: Estimation of the input data for the prediction of road transportation emission in Spain from 2000 to 2010 considering several scenarios, Atmos. Environ., 39, 5585-5596, 2005.

Capaldo, K., Corbett, J. J., Kasibhatla, P., Fischbeck, P., and Pandis, S. P.: Effects of ship emissions on sulphur cycling and radiative climate forcing over the ocean, Nature, 400, 743-746, 1999.

Carney, K. M. and Sydeman, W. J.: A review of human disturbance effects on nesting colonial water-birds, Waterbirds, 22(1), 68-79, 1999.

Clark, C., and Pate, A.: Total flight hours in the Australian Antarctic Territory (AAT) by Australian helicopters and fixed wing aircraft, Australian Antarctic Data Centre - CAASM Metadata, 2001, updated 2006.

Commission for the Conservation of Antarctic Marine Living Resources (CCAMLR) scientific committee reports: Report of the XXIII and XXIV meeting of the scientific committee, online available at: http://www.ccamlr.org/pu/e/e_pubs/cr/drt.htm 2004 and 2005.

Corbett, J. J. and Fishbeck, P.: Emissions from ships, Science, 278, 823-824, 1997.

Corbett, J. J., Fishbeck, P., and Pandis, S. N.: Global nitrogen and sulphur inventories from ocean going ships, J. Geophys. Res., 104(D3), 3457-3470, 1999.

Corbett, J. J and Koehler, H. W.: Updated emissions from Ocean shipping, J. Geophys. Res., 108(D20), 4650, doi:10.1029/2003JD003751, 2003.

Corbett, J.: New Directions: Designing ship emissions and impacts research to inform both science and policy, Atmos. Environ., 37, 4719-4721, 2003.

Council of Managers for National Antarctic Operations (COMNAP): online available at: https://www.comnap.aq/, last access: 2008.

Dannock, G.: Monthly fuel usage (of the main engines, generator sets and boilers) of ships travelling to Australian Antarctic Stations, Australian Antarctic Data Centre - CAASM Metadata, 2002, updated 2006.

Davis, D. D., Grodzinsky, G., Kasibhatla, P., Crawford, J., Chen, G., Liu, S., Bandy, A., Thornton, D., Guan, H., and Sandholm, S.: Impact of ship emissions on marine boundary layer $\mathrm{NO}_{\mathrm{x}}$ and $\mathrm{SO}_{2}$ distributions over the Pacific Basin, Geophys. Res. Lett., 28(2), 235-238, 2001.

Drewery, D. J., Laws, R. M., and Pyle, J. A. (Eds.): Antarctica and environmental change, Proceedings of a Royal Society discussion meeting held on 20 and 21 May 1992, Oxford Science Publications, 1992.

Endresen, Ø., Sørgård, E., Sundet, J. K., Dalsøren, S. B., Isaksen, I. S. A., Berglen, T. F., and Gravir, G.: Emission from international sea transportation and environmental impact, J. Geophys. Res., 108(D17), 4560, doi: 10.1029/2002JD002898, 2003.

Endresen, Ø., Bakke, J., Sørgård, E., Berglen, T. F., and Holmvang, P.: Improved modelling of ship $\mathrm{SO}_{2}$ emissions - A fuel-based approach, Atmos. Environ., 39(20), 3621-3628, 2005.

Enzenbacher, D. J.: Tourists in Antarctica: numbers and trends: Tourism Management report, 142-146, April 1993.

Grübler, A.: A review of global and regional sulfur emission scenarios, Mitig. and Adapt. Strategies for Global Change., 3(2-4), 383-418, 1998.

Hall, C. M. and Johnston, M. E. (Eds.): Polar tourism: Tourism in the Arctic and Antarctic regions, John Wiley and Sons Ltd, Chichester, 1995.

International Association of Antarctic Tour Operators (IAATO) reports: Overview of Antarctic Tourism, online available at: http: //www.iaato.org/tourism_stats.html, 2003/04.

International Association of Antarctic Tour Operators (IAATO): online availabel at: http://www.iaato.org/, last access: 2008.

Kashulina, G., Reimann, C., and Banks, D.: Sulphur in the Arctic environment (3): environmental impact, Environ. Pollut., 124, 151-171, 2003.

Kasibhatla, P., Levy II, H., Moxim, W. J., Pandis, S. N., Corbett, J. J., Peterson, M. C., Honrath, R. E., Frost, G. J., Knapp, K., Parrish, D. D., and Ryerson, T. T.: Do emissions from ships have a significant impact on concentrations of nitrogen oxides in the marine boundary layer?, Geophys. Res. Lett., 27(15), 22292233, 2000.

Kesgin, U.: Aircraft emissions at Turkish airports, Energy, 31, 372- 
$384,2006$.

King, J. C. and Turner, J.: Antarctic climatology and meteorology, Cambridge University Press, 1997.

Kjellstrom, E., Feichter, J., Sausen, R., and Hein, R.: The contribution of aircraft emissions to the atmospheric sulphur budget, Atmos. Environ., 33, 3455-3465, 1999.

Kohler, I., Sausen, R., and Reinberger, R.: Contributions of aircraft emissions to the atmospheric $\mathrm{NO}_{\mathrm{x}}$ content, Atmos. Environ., 31, 1801-1818, 1997.

Langmann, B.: Numerical modeling of regional scale transport and photochemistry directly together with meteorological processes, Atmos. Environ., 34, 3585-3589, 2000.

Lawrence, M. and Crutzen, P.: Influence of $\mathrm{NO}_{\mathrm{x}}$ emissions from ships on tropospheric photochemistry and climate, Nature, 402, 6758, 167-170, 1999.

Lugar, R. M.: Results of $\mathrm{PM}_{10}$ and TSP monitoring at McMurdo station, Antarctica, US Department of Energy, May 1993.

Mazzera, D. M., Lowenthal, D. H., Chow, J. C., Watson, J. G., and Grubisíc, V.: PM 10 measurements at McMurdo Station, Antarctica, Atmos. Environ., 35, 1891-1902, 2001.

Minikin, A., Legrand, M., Hall, J., Wagenbach, D., Kleefeld, C., Wolff, E., Pasteur, E.-C., and Ducroz, F.: Sulphur containing species (sulphate and methanesulfonate) in coastal Antarctic aerosol, J. Geophys. Res., 103(D9), 10975-10990, 1998.

National Atmospheric Emission Inventory (NAEI): online available at: http://www.naei.org.uk/, last access: 2000.

Olech, M.: Human impact on terrestrial ecosystems in west Antarctica, Proc. NIPR Symp. Polar Biol., 9, 299-306, 1996.

Olivier, J. G. J., Berdowski, J. J. M., Peters, J. A. H. W., Bakker, J., Visschedijk, A. J. H., and Bloos, J. P. J.: Applications of EDGAR, Including a description of EDGAR 3.0: reference database with trend data for 1970-1995, RIVM, Bilthoven, 2001.

Oppenheimer, C., Kyle, P. R., Tsanev, V. I., McGonigle, A. J. S., Mather, T. A., and Sweeney, D.: Mt. Erebus, the largest point source of $\mathrm{NO}_{2}$ in Antarctica, Atmos. Environ., 39, 6000-6006, 2005.

Penner, J. Lister, D. H, Griggs, D. J, Dokken, D. J, and Farland, M.: Aviation and the global atmosphere, A special report of the Intergovernmental Panel on Climate Change, Cambridge University Press, Cambridge, 1999.

Pfeffer, M. A., Langmann, B., and Graf, H.-F.: Atmospheric transport and deposition of Indonesian volcanic emissions, Atmos. Chem. Phys., 6, 2525-2537, 2006,

http://www.atmos-chem-phys.net/6/2525/2006/.

Ratcliffe, G., Sheers, R., and Bonnice, J.: Monthly total of fuel used by vehicles at Australian Antarctic Stations, 2001, updated 2005.

Ratcliffe, G., Sheers, R., and Bonnice, J.: Monthly fuel usage of the generator sets and boilers at Australian Antarctic Stations, 2001, updated 2005.

Report of the Norwegian Antarctic inspection under Article VII of the Antarctic Treaty and Article 14 of the Protocol on Environmental Protection to the Antarctic Treaty, Antarctic Treaty, January 2001.

Report of the Committee for Environmental Protection, CEP IX: online available at: http://ncaor.nic.in/scar/zz/scalop_pdf/ SCALOP12_0022.pdf, June 2006.
Report of Inspections under Article VII of the Antarctic Treaty and Article 14 of the Protocol on Environmental Protection: United States Department of State, 12 November-1 December, 2006.

Report of XXX Antarctic Consultative Meeting: The Human Footprint of the IPY 2007-2008 in Antarctica, NewDelhi, online available at: http://www.asoc.org/Portals/ 0/TheHumanFootprintoftheIPY2007-2008inAntarctica\ -XXXATCMIP86.pdf, 2007.

Roper-Gee, R.: Antarctica New-Zealand Information Sheet, Tourism in Antarctica, online available at: http://www.antarcticanz.govt.nz/downloads/information/ infosheets/tourism.pdf, July 2003.

Ship tracking: online available at: http://www.sailwx.info/, last access: January 2009.

Smith, S. J., Pitcher, H., and Wigley, T. M. L.: 2000: Global and regional anthropogenic sulfur dioxide emissions, Global Planet. Change, 29, 99-119, 2001.

Suttie, E. D. and Wolff, E. W.: The local deposition of heavy-metal emissions from point sources in Antarctica, Atmos. Environ. A, 27, 1833-1841, 1993.

Tremmel, H. G., Schlager, H., Konopka, P., Schulte, P., Arnold, F., Klemm, M., and Droste-Franke, B.: Observations and model calculations of jet aircraft exhaust products at cruise altitude and inferred initial OH emissions, J. Geophys. Res., 103, 1080310816, 1998.

United States Environment Protection Agency (EPA): Final Environmental Impact Statement (EIS): Proposed rule on environmental impact assessment of non-governmental activities in Antarctica, online available at: http://epa.gov/oecaerth/ resources/publications/nepa/antarctica/finaleis/index.html, August 2001.

Walton, D. W. H. (Ed.): Antarctic science, Cambridge University Press, 1986.

Wall, D. H.: Biodiversity and ecosystem functioning in terrestrial habitats of Antarctica, Antarct. Sci., 17(4), 523-531, 2005.

Wang, Y., Choi, Y., Zenga, T., Davisa, D., Buhrb, M., Hueya, L. G., and Neff, W.: Assessing the photochemical impact of snow $\mathrm{NO}_{\mathrm{x}}$ emissions over Antarctica during ANTCI 2003, Atmos. Environ., 41, 3944-3958, 2007.

Warren, S. G. and Clarke, A. D.: Soot in the atmosphere and snow surface of Antarctica, J. Geophys. Res., 95(D2), 1811-1816, 1990.

Waterhouse. E. J. (Ed.): Ross sea region, A state of the environment report for the Ross sea region of Antarctica, New-Zealand Antarctic Institute, 2001.

Williams, V., Noland, R. B., and Toumi, R.: Reducing the climate impacts of aviation by restricting cruise altitudes, Transport Res. D-Tr. E., 7(6) 451-464, 2002.

Wolff, E. W. and Cachier, H.: Concentrations and seasonal cycle of Black carbon aerosol in a coastal Antarctic station, J. Geophys. Res., 103(D9), 11033-11041, 1998.

Xie, Z. Q., Sun, L. G., Wang, J. J., and Liu, B. Z.: A potential source of atmospheric sulfur from penguin colony emissions, J. Geophys. Res., 107(D22), 4617, doi:10.1029/2002JD002114, 2002. 